Euskal ikerketen aldizkaria | Revue d'études basques |

Revista de estudios vascos | Basque studies review

$21 \mid 2018$

Numéro XXI

\title{
1940-1960. Nafarroako Bortzirietako neskak Euskal Herriko Iparraldean. "Sasoia"
}

\section{Rosa Arburua}

\section{(2)enEdition}

Journals

Édition électronique

URL : https://journals.openedition.org/lapurdum/3685

DOI : 10.4000/lapurdum.3685

ISSN : 1965-0655

Éditeur

IKER

Référence électronique

Rosa Arburua, «1940-1960. Nafarroako Bortzirietako neskak Euskal Herriko Iparraldean. "Sasoia"», Lapurdum [Linean], 21 | 2018, Sarean emana----an 01 janvier 2018, kontsultatu 23 février 2022. URL: http://journals.openedition.org/lapurdum/3685 ; DOI: https://doi.org/10.4000/lapurdum.3685

Creative Commons - Attribution - Pas d'Utilisation Commerciale - Pas de Modification 4.0 International - CC BY-NC-ND 4.0 


\section{0-1960. Nafarroako Bortzirietako neskak Euskal Herriko Iparraldean. "Sasoia"}

Rosa Arburua

Euskal Herriko Unibertsitatea UPV/EHU

rosamaria.arburuadehu.eus

Nafarroako Pirinietako atarian dago Bortziriak: Bera, Lesaka, Etxalar, Igantzi eta Arantza herriez osaturiko bailara.

Bakoitzak bere xarma berezia du, bakoitzak bere izate eta adorea. Guztiok, istorio paregabea eta errepika ezina.

\section{XX. Mendeko Espainiako Gerra Nafarroan}

1936. urteko Uztailaren 18an, Espainiako gerra zibila hasi zen. Nafarroa, berehala, Francoren alde jarri zen, edo gehiago sakonduz, errepublikak zekarkien ideien kontra.

Nafarroa, bere orokortasunean, Elizan eta bizimodu tradizionalean oinarritzen zen. Gizarteak eta ekonomiak nekazaritzan zituen bere erroak eta gizarte mota honek ideia eskuindarrak aldarrikatzen zituen. Horregatik, nafarrak, foruak eta elizaren boterea arriskuan zituztela ikusirik, horien alde agertu ziren mogimenduaren ondoan jarri ziren. Franco izan zen ideia tradizionalen, elizaren eta orden zehatz baten aldeko liderra; eta, Nafarroa karlista zenez, bat egin zuen errepublikaren aurka zihoanarekin.

J.I. Paul Arzakek (1980), ildo honetatik Beltza aipatzen du:

Para Beltza, el campesinado navarro que toma las armas contra la república lo hace para defender a Dios ya SU Iglesia, al rey ya los Fueros, a la vida estable de una Navarra tradicional y próspera, contra el liberalismo, el capitalismo, el socialismo, la desintegración de su modo de vida precapitalista. ..Es un movimiento, ligado al del siglo XIX, por parte del campesinado todavía no afectado por la industrialización; un .campesinado en estrecho contacto con el clero popular ultracatólico y al que el carlismo se presenta como defensor de sus fueros. 


\title{
Rosa Arburua
}

Berrogeita hamar bat lesakar zeuden lruñan preso; fusilatu behar zituztenean, Lesakako bikarioak haien aldeko txostena bidali zuen, eta horrela, Lesakako bikarioari esker preso gehienak fusilatzetik libratu ziren.

\begin{abstract}
Recuerdo que en Lesaka se llevaron a 40-50 personas a la cárcel, a Pamplona, al fuerte San Cristóbal. Había un cura alto que con sotana y todo no pesaría 50 $\mathrm{kg}$. Había un comandante fanático. El cura fue y le dijo que en su rebaño no había ninguna oveja mala, y si había alguna era por su culpa, y que si había que castigar a alguien que le castigaran a él. (Paul 1995)
\end{abstract}

Esan bezala, erresistentzia txikia izan zuten Francoren aldekoek. Dirudienez, toki zehatz batzuetan besterik ez. Martín de Ugaldek (1982) dioenez:

Prácticamente puede darse por triunfante el Alzamiento en Pamplona y toda la provincia en la tarde del 18, aunque no se declarara el estado de guerra hasta la madrugada del 19. Sólo en Vera, Alsasua y algunos pueblos de la ribera del Ebro hubo que vencer, sin dificultades mayores, determinadas resistencias.

Erresistentzia eza hau Josu Chuecak eta Luis Fernandezek (1997) ere aipatzen dute:

Era berean, errepresioa ez zen inolaz ere ezkerraren erresistentzia menderatzeko saioa. Apenas izan baitzen erresistentziarik. Beran, lrundik joandako milizianoak eta bertako ezkertiarrak uztailaren 19an herriaren jabe izan ziren, baina 24 ordu eskas iraun zuen egoera horrek.

Egoera honela, eskuindar taldeak ez zuen lan handirik izan Nafarroa eta nafarrak bere alde ager zitezen.

\subsection{Guda ondoren}

En el dia de hoy ,cautivo y desarmado el ejército rojo, han conquistado las tropas nacionales los últimos objetivos militares. La guerra ha terminado.

Hitz hauekin amaitutzat jo zuen Francok hainbeste sufrimendu sortarazi zuen gerra zibila.

Nahiz eta 1937ko ekainean ofizialki gerra bukatutzat eman, euskaldun askoren errealitatea beste bat izan zen, urtetan egon baitziren batzuk oraindik armadaren menpe; eta beste asko, berriz, preso Espainiako kartzeletan.

Guda ondorengo lanak hasi ziren. Lan fisikoak, eta psikologikoak ere bai. Bizia aurrera zihoan, familiak mantendu behar ziren, aurrera egitea besterik ez zen geratzen.

Euskal Herriari dagokionez, badirudi 1936-37 bitartean, 156.000 bat pertsonak aldegin zutela lurraldetik eta hauetatik 63.000 (ez eta erdia ere) bueltatu zirela. Iheslaria gizona zenean, familiak mehatxua izaten zuen. 


\section{Rosa Arburua}

...beranduago ere bai, Vicente Lanzek Frantziara ihes egin zuenean, bere emazte Ramona eta bere semeak lruñara eraman zituzten. Gero, kontatzen zidanez, behin baino gehiagotan fusilatuak izateko zorian egon ziren. (Paul 1995)

Gudaren bertze ondorio garrantzitsu bat jaiotza tasarena izan zen. Gerra aurretik eta Berako Balkezeneko Anttoniok dioenez, 9-10 senideko familiak nonahi zeuden. Gerra ondoren eta urte batzuetan, ezkontzak murriztu egin ziren eta haur gutxi jaio ere bai. Bost bat haur edo izaten omen zen gerra ondorengo familietan. Testigantza honen arabera, erdira jeitsi zen familia berrien haur kopurua. (Arburua 2005)

Fernando Merino Rodriguezek (1984) Bortzirietan, 1930 urtean,7.956 pertsona bizi zela dio. Hamar urte beranduago igoera nabarmena ageri da: 9.032 pertsona. Baina 1940tik 1950 bitartera (gerra ondoren) jaitsiera dugu nagusi: 8.231 pertsona. Bortzirietako herririk nabarmenena, jaitsierari dagokionez, Lesaka dugu. Hamar urtez, (1940-50), 3.445 pertsona izatetik, 2.169 izatera pasako da. Ez zen haur gutxiago jaio zelako bakarrik, emigrazioak ere, Ameriketara joateak zerikusi handia du jaitsiera honetan.

Ekonomiari dagokionez, gerra aurreko lanbidea baserrian oinarritzen zen. Dirua, sosa, gutxi erabiltzen zen eta baserrian bertan egindako produktuez elikatzen zen familia.

Gerra ondoren, Espainiako zenbait lurraldetan gosetea ezagutu zuten, baina Nafarroako Bortzirietan, hainbat testigantzaren arabera, ez zen horrelakorik gertatu. Harez gehiago, ondoko hirietako jendea bertako baserrietara joaten omen zen, janaria erosteko asmoz.

Baserrietako familiek goserik ezagutu ez bazuten ere, produktu gutxirekin elikatzen ziren: babak, ilarrak, taloak, esnea, gaztaina eta ezer gutxi gehiago. Azukrea, xaboia, tabakoa, olioa. ..errazionatuta zeuden.

Ogia baserrian eginez gero, aste osorako egiten zen.

Berako Arroxalinek, beraiek baserritik eskolara janaria eramaten zutela eta ez zutela goserik pasa zioen. Sobratzen bazitzaien zertxobait, han egoten omen ziren guardia zibilen haurrak, hartzeko prest. (Arburua 2005)

\subsubsection{Eskolaratzea}

Nafarroan 1900 urtean, gizonezkoen artean, \%40k ez zuten ia eskolarik. Emakumeen artean gehiago ziren eskola gabekoak, \%56.

1831 urteko eskola araudiak bortz eta hamabi urte bitarteko haurrak eskolaratzea behartzen bazuen ere, ez zen horrela suertatzen. Etxeetan lan handia izaki eta haurrak aunitz faltatzen ziren eskolara. 


\section{Rosa Arburua}

Eskolan funtsezkoa ikasten zuten: irakurri, idatzi eta matematikako lau erregelak. Kristau dotrina eta zenbait tokitan, fundamentu pixka bat bazen, geografia kontuak ere izaten ziren. Erderaz, noski.

Zenbait herritan Para mi hijo liburua erabiltzen zen.

lzuak agintzen zuen mutilen heziketan. Garai hartako emakumeek ez dute horrelako oroipen txarrik. Etxalarren esaterako maistra on bat omen zuten, ona eta neskek ikas zezaten interesa jartzen zuena. Neska asko gelditu zen ikasketetan aurrera jarraitu ezinik eta penatan. Mikelaren kasua barne. Baserrian anaia bat sortu zen; eta arrebak 12 urte zituenez, nahiko eskola ikasi zuela pentsatu zuten etxekoek eta anaia zaintzeko ardura eman zioten. Irakaslea bera joan omen zen baserrira Mikelak eskolara joaten jarraitu behar zuela erraiteko, neskak horretarako balio zuela eta, baina alferrik. (Arburua 2005)

Berako neskak monjetara joaten ziren eta oroipen ona dute garai hartaz ere.

Mutilen kasua guztiz kontrakoa da. Palizak eta errietak egun guziez gertatzen ziren.Irakaslek ez zuten inolako gogorik irakaskuntzan aritzeko. Haziendak balira bezala tratatzen zituzten mutikoak.

Egoera hau ezaguturik, mutiko gutxik jarraitu zuten ikasketetan nahiz eta zenbait baserritan behar adina diru izan. Hau Berruta baserrian gertatu zen. Bertako Avelino, beste mutikoak bezala, eskolara joaten zen baina bertan paliza eta ikara bertzerik ez zuen ikusi. Bere ama Arroxak, 12 urte bete zituenean, Albaitari izatea gustatuko zitzaiola erran zion bere semeari. Honek, ez eta horrelako historioz inominatzeko ere, gogor jokatu zuen, bera inolaz ere ez zela gehiago eskola kontuetan ibiliko. Guztiz barneratutako izuak solas egin zuen. (Arburua 2005)

Erran bezala, gerra ondorengo mutikoa eta neska gehienak eskolara joaten ziren.

Arantzako kasua dugu aparta. Esteban lrigoien apaiza bertara erretore lanak egitera joan zenean herriaren analfabetismo nabarmenak guztiz hunkitu zuen. Ez omen ziren eskolara joaten eta gutxi batzuk izan ezik, ez omen zekiten bere izenez sinatzen ere.

Bertara joaten ziren irakasleak ezer gutxi irauten omen zuten, inolako formalidaderik ez omen zegoen eskola kontuetan. Zerbait egin behar zelakoan, irakasle euskaldun baten bila hasi ziren, alde batetik eta bestetik. Aldi berean, irrati klandestino bat martxan jarri eta bertatik eskolaratzearen garrantziaz informatzen zuten.

Sunbilan maistra baten berri izan zuten eta berari eskaini Arantzako eskolan lana, baina euskaraz ez zuen irakatsi nahi. Beste neska baten berri izan zuten, Sunbilakoa bera, Ezkerro abizena zuena. Tituluduna, baina Leridan erizain lanak betetzen ari zena. Harremanetan jarri ondoren, baiezkoa eman zion Estebani Arantzara joateko eta euskaraz irakasteko. 


\section{Rosa Arburua}

Orduan, hezkuntzako inspekzioarekin, Gurpide jaunarekin batez ere, izan zuten arazoa baina azkenik lortu zen.

Hiru txanda izaten omen ziren eskolan. Alde batetik haurrak, gero gazteak eta ilunabarrean helduak. Haur eta gazte 100 bat ikasle ziren.

1960. urtean, lrigoienen esanetan, 14 urtetik 40ra bitarte, Arantzako biztanleak, oro har, analfabetoak ziren, baina pixkanaka-pixkanaka egoera izugarri hau gaindituz joan zen.

Analfabetismo latz hau Arantzan gertatzen zen aldi berean beste muturreko kasua dugu Baztango Iruritakoa. 1940 urtean herri horretan 800 bat biztanle bizi zen. Haietako 20k unibertsitatean ikasten zuten; eta beste askok Iruñeko San Juan Seminarioan aurrera eramaten zituzten ikasketak.

Aurrerago aipatu bezala, neskak 12 bat urte bete arte joaten ziren eskolara. Gero, 16-17 urte arte baserrian egoten ziren, bertako lanetan laguntzen. Baina gero, asko behintzat, josten ikastera joaten ziren. Herriek irakasleak zituzten. Beran monjek irakasten zuten. Garai hartako neskek ezkondu aurretik josten jakin behar zuten, guztiz inportantea zen.

Etxalarren garai hartan hiru irakasle zeuden:

- Felixa. Bere lehengusina Parisen aritzen zen jostunean, batzuek Dior etxean, diote, beste batzuek, Balenziagarekin.

- Erraneko bi aizpa.

- María Gorosustakoa.

Neska gazteak horiengana joaten ziren josten ikastera. Ez zuten ordaintzen, ikasi ondoren lanarekin ordaintzen zituzten ikasketak. Udan ez ziren joaten; neguan bakarrik eta herriko festen aitzinean ere bai.

Horietako gutxi batzuk joaten ziren Donostiaraino josteko ikasketak egitera, beti ere bertan edo inguruan familia bazuten. Antxumeko Benita izan zen horietako pribilegiatu bat. Berak, 1945 urte inguruan, Gilda Espainiara etorri zen albistea izan zuen eta, Donostiako jostun ikasleak interes guztia jarririk, zeramatzan arropen berri jaso zuten: arropa luzea erabiltzen zuela harriduraz komentatuz. (Arburua 2005)

\subsubsection{Lanak}

Mutil gazteek, eskolako lanak amaitu eta gero, baserrietan lan egiten zuten, norberaren baserrian, edo mutil bezala beste baserri batera lan egitera joaten ziren. Bi eratara aurrera eraman zitekeen lanbide hau: 


\title{
Rosa Arburua
}

- Baserrian lan handia zegoen uneetan, adibidez, belar sasoian edo-eta iratze lan garaietan. Berako Balkezeneko Anttonio lan hauen mutil dugu. Iratzea pikatzen aritzen omen zen berea ez zen bertze baserri batean. "Ongi leher egin eta gero 10 pezetako jornala ematen zidaten eta mantenua ere bai".

- Baserriko morroi, urtetan. Lesakako Ignacio Zubiria lan honen lekuko. Bere baserrian senide guztientzat ez omen zegoen lanik eta, hau garai hartako mutiko gaztea, 14 urtekoa, bertze baserri batera joan zen mutil, mantenu eta jantziaren truke.

Bortzirietan 1940 urtetik aurrera, baserritik aparte bertze lanbide batzuk suertatu ziren. Beti ere baserria eta honen inguruko lanak izanen ditugu ardatz; baina honez gain, mendiko lanak, Terranovako bakailaoak, Ameriketara emigratzeak, kontrabandoa eta Iparraldeko ostatuetan neskek egindako "sasoiak" dira azalduko zaizkigun Bortzirietako garaiko gazteentzako lanak.

Bai, Nafarroako iparraldeko neskek, Euskal Herriko Iparraldeko hoteletan, ostatu, jatetxeetan... Maiatzean hasi eta Urria bitarte lana izaten zuten. Honi, sasoia egitea deritzoten.

Beraien erranetan, lana gogorki eginez, garai hartako diru aunitz zena irabazi zuten. Kontent joaten ziren sasoia egiterat. Beraien herrietan baserriko lanetik aparte besterik ez zegoenez, irteera hau ekonomikoa zen, baina aldi berean, hain hurbil zuten beste mundu batera alde egiteko aukera eskaintzen zien.

\section{Sasoia}

\subsection{Non dira emakumeak?}

\author{
Eskerrak emakumeok haurrak ekartzen ditugun mundurat, naturak hori ere utzi \\ ez baligu, ez ginateke existituko! (Arburua 2005)
}

Lami zoragarriak edo sorgin beldurgarriak agertzen dira gure kroniketan, baina emakume langileak, ausartak edota bere kabuz bizitza aurrera eraman dutenak...apenas.

Emakume inportanteak, artistak, maitaleak edo gizonen tokia-lana denok harrituz bete duenik ere badago, haien biografiari buruz badakigu. Hor ditugu, esaterako, Anduraingo Marga kondesa, (1895-1948), emakume aberatsa, garaiko abenturazale amorratua, edo Bitxori Etxeberria Elizondokoa, Itziar Mugika eta Delia Lauroba donostiarrak, eta Tere Verdes bilbotarra. Azken lau horiek errepublikazaleak omen ziren eta 1923an sorturiko Emakume Abertzale Batzako kideak izanik, Gerra zibilaren ondoren espioitza lanak egin zituzten. Maritxu Anatol irundarra ere aipagarri dugu (1909-1981), Aduana Agentzia zuten 


\section{Rosa Arburua}

familiako alaba, kontrabandista bera, alemanen aurka informazio kontrabandoa egiten zuena.

Badago, bai, emakume ospetsurik, baina banaka edo oso talde txikiaren barruan nabarmendu direnak.

Emakumeak talde bezala eta historian zehar, denboraldian zehar eta testimonio idatzia utzi duenik, nik dakidanez, bat bakarrik: Erronkari aldetik 1880-1930 urte inguruetan Mauleko espartin fabriketan lan egiterat joaten zireneko neska talde galanta.

Hauek oinez, Fago, Izaba, Antso, Uztarroz, Hecho, Erronkari herrietatik udazken bukaeran Mauleraino iristen ziren. Bi edo hiru egun behar izaten zuten Izaba, Belagua, Juan Pito eta Urdaite lepoa zeharkatuz bere lantokira iristeko.

Emakume hauek diotenez, espartinak egiteko lana gogorra zen, baina lantokian abestiak, irriak eta bromak ugariak izaten ziren. Garaiko zenbait neska Maule inguruan esposatu ziren: besteak, gehienak, beraien herrirat itzuli ziren, besteak beste, esposetako gauzak erosirik. (Inchauspé 2001)

Bada, aurreraxeago ikusiko dugunez, berdintsu gertatuko zen 1950 urtetik 1965 bitarte, batez ere, Bortzirietako neska gazteekin.

Lehen aipatu dudan emakume falta hau historian zehar, zenbait adituk (emakumezkoek batez ere) azpimarratu izan dute. Asko gustatu zitzaidan, Encarna Hidalgok (1996) esana:

\footnotetext{
No sé si es más nefasto que las mujeres "no tengan" historia o que la historia no tenga mujeres, con las consecuencias que comporta para la disciplina el hecho de despreciar la riqueza de la tradición de la mitad de la humanidad.
}

Beno bada, bistan da hemen gaudela eta gizakia gizaki denez geroztik emakumea ere emakume izan dela eta badugula geure historia, ez emakume bezala bakarrik, gizaki bezala, batik bat, ere bai.

Dena den, ez dut gustuko emakume-gizaseme dikotomia -parekatze hori egitea. Badirudi errebindikazioa dela eta gizonen aurka hartzen dela, gerraren bat izango balitz bezala. Ez. Bada tokia denontzat eta denok-bakoitzak dugu tokia. Baina ez zaigu apenas agertzen historian zehar emakumeak kolektibo bezala zein toki izan duen eta nolakoa izan den.

Esan dudanaren adierazgarri, Bortzirietan 2000-2002 bitartean egindako lan aipagarria. Euskara Mankomunitateak beka bat zabaldu zuen Bortzirietako Aho literaturari buruz bilduma egiteko asmotan. Horretarako, hainbat elkarrizketa burutu zen, eta andre-gizonek parte hartu zuten. Helburua ipuinak, kondairak... biltzea bazen ere, azkenean Bortzirietako bizimoduaz, ohiturez, lanaz... hitz egin zuten elkarrizketalditakoek. Emakumeek agertzen dituzten gaiak gehienbat dira etxea, familia, barneko harremanak, garbiketa kontuak, 


\section{Rosa Arburua}

janzkera eta orrazkera, elikadura... Ez da inolako aipamenik Sasoiaren inguruan. Baliteke kasualidadez elkarrizketatutako emakumeen artean ez inor egotea Sasoia egin zuenik, baliteke. Edo, agian, nahiz eta Sasoia kontuetan ibiliak izan, ez inolako garrantzirik ematea horrelako lanari, baliteke.

Baina izan, izan zen neska multzo ederra, Bortzirietatik Lapurdiko hoteletarat lana egiterat joan zena. Horietako hainbat Parisen ibiliak dira etxe partikularretan neskame lanak egiten eta joan ez zirenetatik penatan gelditu zirenak ere bai.

\subsection{Emakumeak XX. Mendeko guda inguruetan}

XX. mendean zehar, Europak bi gerrate jasan zuen. Eta ondorioek jendearen bizimoduak eta sentimenduak errotik aldatuko zituzten.

Lehen gerrate mundialak hainbat fabrika ixtera eraman zuen, bertan lan egiten zuten gizonak beste "lanetara" eramanak izan baitziren.

Gudak uste baino luzeagoak izanen zirelakoan eta gerratea mantentzeko zenbait produktu fabriketan egin behar zirelako, emakumeak hasi ziren etxetik kanpo lan egiten. Dena den, argi geratu zen egoera hura denboraldi baterako izanen zela.

Badirudi Europako armamendu fabriketan emakumeek osatzen zutela langileen kopurutik laurdena. Etxetik kanpo lan eginda ere, ez ziren libratu emakume horiek etxeko lanetatik eta denbora denetarako behar zenez, fisikoki itxura aldatuz joan ziren garai hartako emakumeak: fabriketan lana erosoago egin zezaten, gonak moztu zituzten, ileak ere moztu zituzten, eta horrela lan gutxiago zuten gauza horiek dezente mantentzen.

Lehen guda bukatu ondoren, emakume gehienak etxeko lanetara itzuli ziren, eta pentsaturik zenbat lanordu egina zuten bai etxean baita lantegietan ere, ulertzekoa da gustura hartuko zutela gerra ondorengo egoera lasaiago hura.

Bigarren munduko gerratearekin, 20 urte geroago, berdintsu gertatu zen: gizonezko asko gudara joan zen; eta lanpostuak, zenbait behintzat, emakumeek bete behar izan zituzten; baina lanari buruzko pentsamoldeak aldatu ziren. Orain garbi zegoen emakumeen lana behar-beharrezkoa zela eta emakumeari, gizakia izanik eta horrela kontsideraturik, beste balio bat eman zitzaion.

1936. urtean, Espainiako gerra zibila hasi zen, 39an frankismoaren garaiarekin aurreko garaiko askatasunak desagertu ziren.

II. Errepublika garaian emakumeek zuten hainbat eskubide deuseztatu ziren: hauteskundeetan parte hartzea eta dibortzioa esaterako. 


\section{Rosa Arburua}

Emakumea aitaren menpe geratu zen lehendabizi eta bere senarraren menpe gero. Egoera hori horrela mantentzeko, hezkuntza sistemak zerikusi handia izan zuen.

1950. urte inguruan, gerrak utzi zuen gosea, nekea eta sufrimendua gainditzen joan ziren poliki-poliki.

Industriagintza oraindik geldirik zegoen atzerriko lurraldeek Espainiari ateak itxi baitzizkioten. Baina egoera hori hamarkada honen erdi alderat aldatzen joan zen. Soldatak murritzak ziren garai horretan, eta horregatik emakumearen soldata behar-beharrezkoa izaten zen familia askotan. Europan, 50eko hamarkadan emakumeek etxetik kanpo lan egiten bazuten, garai oparoari esker zen; eta etxeko lanak erraztuko zituzten tresnak asmatu zirenez, denbora gehiago zuten europar emakumeek etxetik kanpoko lanbideren batean aritzeko.

Espainiako egoera arrunt bestaldekoa zen. Emakumeek etxetik kanpo lan egitera beharturik zeuden, diru falta izugarria izanik, beraien soldata murritzek ongietorria izaten zuten famili egoera miserable haietan.

1937-1957 urte bitartean jaio eta haurtzaroa igaro zuten emakumeek garai latzak bizitu zituzten. Egoera ekonomiko larrian eta kultura maila eskasean hazi ziren.

Diktadurak, hezkuntza eta erlijioaren bitartez, argi erakusten zuen emakumearen "tokia" zein zen: emakumea gizonaren menpe egon beharreko gizakia zen: obeditu eta isildu eta etxetik kanpoko ekintzetan ezer gutxi murgildu.

A. de Guevarak ongi aski adierazten dizkie gizon eta emakume ezkon berriei bakoitzaren betebeharrak:

El oficio del marido es ganar hacienda, y el de la mujer allegarla a guardarla. El oficio del marido es andar fuera a buscar la vida, y el de la mujer es guardar la casa. El oficio del marido es tratar con todos, y el de la mujer hablar con pocos. El oficio del marido es saber bien hablar, y el de la mujer precisamente de callar. El oficio del marido es celar la honra, y el de la mujer preciarse de muy honrada. El oficio del marido es ser señor de todo, y el de la mujer es dar cuenta de todo. El oficio del marido es granjear la hacienda y el de la mujer es gobernar la familia. (Arburua 2005).

Garai horretan penintsulako emakumeen artean, ez eskolatuak mutiletan baino \%50 gehiago ziren. Bestalde, oso emakume gutxik egin zituzten 2. mailako ikasketak. 


\subsection{Nafarroako Bortzirietako neskak}

Garai honako Bortzirietako emakumeek ez zuten fabriketan lan egin, ikertutako garaian, ez baitzegoen fabrikarik inguru honetan. Baserrietan lana egiten zen eta etxe inguruan jorratzen zen bizimodua.

6-12 urte bitarte, gehienak eskolarat joan ziren (beste atal batean aipatu dudanez, aparteko kasua dugu Arantzakoa. Bertako neska-mutil gutxi ibili ziren eskola kontuetan). Gehienek diote Matematika, irakurri-idatzi eta geografia ikasten zutela eskolan. Garai hartako gelako haur kopurua handia zen, handiegia. Etxalarko eskolan, 60 urteko maisuarentzat 60 haur omen zeuden eskolaratzeko.

Neska eta mutilak aparte, gela banatan, nahastu gabe.

Neskei dagokienez, askotan ikasteko gogo handia azaltzen omen zuten; interes handiarekin joaten omen ziren eskolarat. Gustura jarraituko omen zuten eskolara joaten, baina baserriko lanetan lagundu behar zutelako edo anai-arrebaren bat jaio zelako eta hura zaindu behar zutelako, neska askok bukatutzat eman behar izaten zuten ikaskuntza.

Hala Mikelaren kasua. 12 urte zeukan eta ikasturtea bukatutzat emandakoan, eskolarat gehiago ez zela joango erran zion bere maistrari. Irakasle aparta omen zen emakume hura eta Mikela posibilitate handiko ikaslea, berak esan zidanez: Geografia kontuetan gelako bigarrena; lehenengoa M. Jesus Etxeberria izaten omen zen. Honek ile apaingarri ikasketak egin zituen aurrerantzean.

Bada, irakaslea, Mikelaren baserrira joan omen zen haurraren amarekin hitz egiteko asmotan, ikasketak luzatzeko proposamenarekin. Alferrik. Anaia bat zaindu behar zuen eta ezin zen gehiago joan eskolarat. Gaur egun, Mikela eta bere anaiak ez dute inolako harremanik, herentzia kontuak direla eta. Nola gertatzen diren kontuak!

Mikelak honela dio:

Nik posibilidadia izan banu zuek bezala (nitaz), medikuntza eginen nuen. Aunitz gustatzen zitzaidan eskolara joatia. Neretzat izugarria izan zen martxa hura pikatzia. Baina... amak agindu zuen.

Emakume honi gaur egun ere, aunitz gustatzen zaio medikuntza mundua eta bere kabuz hainbat liburu irakurri du, beti ere medikuntza alternatea nahiago du baina.

Nahiz eta gure denbora eremutik kanpo egon, iruditzen zait aipatzekoa dela 1930. urte inguruan gertatutakoa. 


\section{Rosa Arburua}

Aurita Osuna Etxalarko farmazialari izanen zena dugu kasu berezietako bat. Bere aita Jose, bertako farmazeutikoa izan zen urte aunitzetan.

Aurita, hiru senidetik zaharrena zen. Lehen hezkuntza bukatu ondoren Batxilergoa egin nahi zuela erran zuen etxean. Hau ez zen batere ohizkoa garai hartan. Horrela, Batxilergoa egin eta bere aitak bezala Farmazia egin zuen. Salamancara joan zen lehenbizi eta, gero, Madrilera. Auritak berak zioenez, Madrileko Unibertsitatean, nahikoa neska omen zegoen Farmazia ikasi nahian, baina ikasketak bertan-behera uzten omen zituzten ezkontzeko garaia iritsita.

Ikasle batek ez omen zuen batere gustuko gelan hainbeste neska edukitzea. 100 bat neska omen zen garai horretan farmazia ikasten Madrilgo Unibertsitatean.

Jose, Auritaren aita, Urrotzera joan zen farmazia lanak betetzera eta Etxalarko hutsunea bere alabak bete zuen.

Aztertzen ari garen urteetara itzuliz, Lehen hezkuntza bukatu ondoren eta urte batzuk baserri inguruetan laguntzen ibili ondoren, neska aunitz josten ikasterat joaten ziren. Hau guztiz inportantea izaten zen, behar beharrezkoa.

Mikela, adibidez, 17 urteetan hasi zen kontu horietan. Goiz eta arratsalde joaten ziren. Gero, josten ongi ikasi ondoren, berak egiten zituen arropak familiakoentzat:

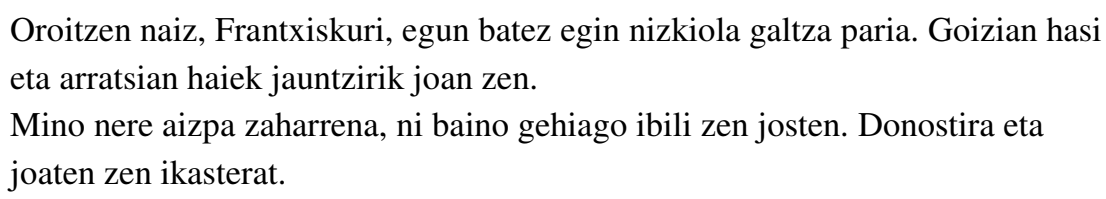

Benita Goienetxe Donostian ibili zen josten ikasten. Berak, Pasaian familiakoren bat bizi zuelako, aukera hau izan zuen. Autobusez joaten zen bertara; astea Pasaian ematen zuen; eta handik Donostiara joaten zen ikastera; eta astebukaeretan baserrira itzultzen zen. Bere erranetan, 1945. urtean ustez, Gilda aktoresa Madrilerat etorri zen; eta gertakizun hura izugarria izan zen jostunen artean, zeren eta bere jantziak luzeak ziren, garai hartan ez ohizkoak arrunt.

Benitak Etxalarko Dominika aipatzen zidan bera bezala josten ikasterat Donostiaraino joaten zena. Hark ahizpa omen zuen bertan esposaturik, eta horregatik aukera pare gabe hau.

Beste batzuek, neskame kontuetan gazte-gazterik hasitakoek, ez zuten asti handirik izan josten ikasteko; baina betiere, edo egun libreetan edo lanik gabe gelditzerakoan, josteko ikasketak egiten zituzten. 


\section{Rosa Arburua}

Aunitz dira, eskolako lehen ikasketak bukatu, baserrian urte gutxi batzuk laguntzen pasa eta neskame joaten zirenak. Lan baldintzak eskasak izaten ziren. Emakume hauei zertan lan egiten zuten galdetzerakoan, denetatik egin behar izaten zutela diote, etxeko lanak, haurrak zaindu, garbitu... momentuan tokatzen edo agintzen zietena. Ez zuten aunitz irabazten. Zenbait kasutan, mantenua eta noizean behin propinen baten truke pasatzen zituzten urte batzuk. Horregatik, Iparraldeko hoteletan lan egiteko aukera izan zutenean, inolako dudarik gabe bigarren lan honi atxikitzen zitzaizkion.

Silvia Fernandezek eta Paco Rodak (1998) diotenez:

\footnotetext{
La niña que era contratada para trabajar en una casa no tenía ningún contrato. Generalmente su trabajo era duro y lo hacían bajo unas condiciones muy exigentes. Pero se trataba de buscarse la vida, de ganar algún dinero para poder pagarse la dote exigida en un futuro matrimonio.
}

Igantziko Fabiola Hendaiako polizien buru zenaren etxerat neskame joan zen15 urtetan. Gero Iruna, Porcelanas del Bidasoako enkargatuaren etxerat. Han, 500 pezeta irabazten omen zuen hilabeteko. Bigarren etxe honetan, etxeko lanak egiteaz gain, haurrak ere zaindu behar zituen eta ez omen zuen batere gustuko.

Etxalarko Anuntxi ere, gazte-gaztetik, lehenbizi Irungo familia batera eta gero Donostiara joana zen. Bere anaiak dioenez, Anuntxi ez zen Etxalarko bizimoduaz enteratu ere egin. Kanpoan bizi zen, anaiarentzat arrotza zen.

Dena dela, josten ikasten ibili edo neskame lanetan aritu, 1950-60ko hamarkadan 20 bat urte zuten Bortzirietako neska aunitz Euskal Iparraldeko ostatuetarat joaten ziren sasoia egiterat. 1960. urtetik gora ere joaten ziren; baina nire ustez, motibazioa dirua irabaztea zelarik, etxeko egoera desberdina izaten zen, eta presio ekonomikoa ere bai.

Jasotako datuen arabera, etxalartarrak eta beratarrak ditugu gehien bat lan hauetan arituak. Agian mugatik gertu-gertu egoteak zerikusia izan dezake. (Arburua 2005).

Sasoia hitza, frantseseko Saison-etik dator, udako garaia, garai hartako frantsesen egoera ekonomiko positiboaren oporraldia. Paris aldetik Ipar Euskal Herriko hainbat hoteletarat, familiak etortzen ziren uda zati bat igarotzerat. Haiek ongi zaintzeko, jendea behar zen eta hor zuten aukera paregabea Bortzirietako neska langileek dirua eta beste bizi modu bat ezagutzeko.

Udako hiru hilabeteetan, Bortzirietako zenbait neskak beste aldeko hoteletan lan egiten zuten edo, gutxi batzuk, etxe partikularretan neskame gisa. Egoera hori norberaren garapenerako hagitz garrantzitsua izan zen.

Douglass antropologoak (1977) zera zioen: 


\section{Rosa Arburua}

La recuperación de la economía francesa y la prosperidad general de Francia originaron una demanda laboral, sobre todo en el área de los trabajos domésticos, situación de la que se aprovecharon algunas jóvenes de Echalar. En ciertos casos, las chicas han pasado temporadas en el País Vasco Francés, en hoteles de turistas y por lo tanto saben francés...En 1960, 32 chicas de Echalar estaban trabajando en Francia ( 8 de ellas en París).

Neska horiek aukera izan zuten beraien sor lekuak eskaini ez zezakeen dirua irabazteko modua eta "beste mundu bat" ezagutzeko.

Douglassek dioen bezala, Frantziak 1950. urte inguruan garapen ekonomiko handia lortu zuen; aldiz, gure herrietan oraindik gerra ondorengo iluntasunak ez du argitzerik izan. Bi egoera horien artean, mendi batzuk besterik ez.

Ipar Euskal Herria garai haietan, orain gertatzen den antzera, erabat turistikoa zen. Hotelak barra-barra zeuden eta uda zen lan egiteko garaia. Langileak behar ziren eta hara joan ziren gure protagonistak. Langileak diot, neska langileak. Lekuko askok diotenez, neska euskaldunak, lana aunitz egiten zuten, dirua irabazi, bai, baina lanordu asko igaro ere bai, gehienetan inolako kexarik gabe. Hau nahi izaten zuten nagusiek: lana egin eta ongi egina izatea. Bortzirietako neska gehienek baldintzak betetzen zituzten.

Batzuk, Iparraldean edo Paris aldean gelditu ziren bizitzen. Hauetatik, gutxi, bertan esposatu zirelako eta besteak bere lanbidea han zutelako. Dena den, badaude jubilatu ondoren etxeratu direnak, nahiz eta noizean behin Paris alderat joan egun batzuk pasa: Etxalarko Akoka baserriko Milagros Indaburu adibidez.

Hainbat emakumeen sasoia egitearen esperientzia ahoz jaso dut; eta nahiz eta bakoitzak bere ezaugarriak izan, denek, nire ustez, badituzte komunak direnak ere:

- 12-13 urte arte, gehienez, joan ziren eskolarat.

- Sasoia egiterat norbaitek erran eta joanak izan ziren. Ahoz eta laguntasunaren medioz lortzen zen lana. "Gidaria" sasoia egiten aritua edo aritzen zen.

- Sasoia egin, bi arrazoirengatik egiten zen: alde batetik, behar ekonomikoak bultzatzen zituen; bestaldetik, zenbait kasutan, diru premiarik ez bazegoen ere, askatasun eta ezagupenaren beharrak bultzatzen zuten zenbait.

- Neska ausartak ziren, gogoz joaten ziren ezezaguna egiten zitzaien tokira.

- Langile porrokatuak ziren neska haiek. Lana egiten, eta ongi egiten ere, usatuak ziren.

- Ikasteko inolako arazorik ez zuten. Alderantziz, bertan, sasoia garaian, ikasitakoa eskertzen dute. Aunitzek frantsesa ikasi zuten. Baten batek gida baimena bertan 


\section{Rosa Arburua}

atera zuen eta denak ere beraien herrietan ikas ez zezaketen eguneroko hainbat gauza barneratu zituzten.

- Ez zen lana bakarrik. Ongi pasatzen zutela diote. M. Luisa Iparragirrek erran zidan bezala: "bai guk viva la juerga ere egiten genuen!!!”.

- Hasiera batean ez zuten asegururik. 57tik aurrera joandakoak gehienak, bai, baina aurretik ibili zirenetatik gutxi batzuk egon ziren aseguraturik. Garai hartan eta Bortzirietan aseguru konturik entzun ere egiten ez zelako, aseguruak nagusien baitan, haien borondatearen arabera izaten ziren; eta erran bezala, gutxi zeuden paperak behar bezala osaturik. Gaur egun arazoak sortu dira honen gainean. Emakume horiek, jubilatzerakoan, Frantziatik pagaren bat badute jasotzea. Hendaiako Udalak, garai batean, kasu horiek aztertzen zituen eta zenbait emakume oso paga txikiarekin gelditu izan dira, urte gutxiz izan baitziren aseguratuak. Beste batzuk, batere ez, eta beste zenbait, legalki dagokien diruarekin. Denetatik.

Igantziko Fabiolaren kasua dugu aipagarri. Hiru urte egon omen zen paperik gabe. Inspektore bat hotelera joan omen zen eta horren ondorioz, bertan lan egiten zuten guztiek izan zuten legezko dokumentazioa.

Mikelak paga txiki bat badu, "ilobei txutxeak erosteko, ez aunitz gehiago!”.

Donibane Lohitzuneko Kapagorri hoteleko nagusia guztiz zuzena zelako graziaz.

Maittere orain jubilatzeko dago eta harat honat dabil paperak betetzen eta ezusteak ezagutzen. Lanaren herena agertzen zaio aseguraturik.

- Garai latz haietako, eta sosik sumatu ez zuten neska horientzat, diru aunitz irabazten zuten. Diru hori, kasu gehienetan behintzat, ezkontzeko tresneria eta arropa-maindire erosteko erabiltzen zuten. Beraientzat, "arropa politak" erosten zituzten eta etxekoentzat, momentuan behar zutena edota opariak ere bai.

- Kasuren batean, etxekoen behar ekonomikoak betetzeko joaten ziren neska horiek lan egiterat; baina gehienetan, nahiz eta inolaz ere diru soberantziarik ez egon, nesken beharrak, eta batez ere ezkontzeko beharrak, betetzeko joaten ziren sasoia egiterat.

- Orokorrean ongi tratatuak izan ziren, errespetuz, eta askotan, maitasunez.

- Neska horiek lagun minak egin zituzten eta zenbait kasutan, nahiz eta elkarrengandik urruti bizi, oraindik ere elkar ikusi eta garai haietaz alaitasunez mintzatzen dira. 


\section{Rosa Arburua}

- Herrietara moda berriak ekarri zituzten. Garai hartan,1955-60, neskak beltzez jantzita esposatzen ziren. Mikela, Iparraldean ikusitako moda jarraituz eta herriko jendeen kritika galantak jasoz, soineko luze eta txuriz ezkondu zen.

- Sasoia esposatu zirenean bukatu zen.

- Batzuentzat, sasoia Pariserat lana egiterat joateko tranpolina izan zen. Pariseko jendea Iparralderat joaten zen oporraldia igarotzera; eta bertan, hoteletako nagusiei neskame baten berri ote zekiten galdetzen zieten. Han lan egiten zuten neskeei galdetu ondoren eta interesik agertzen bazuten, bada, harremanetan jartzen ziren eta, horrela, Pariseko bidea hartu.

Gutxi batzuentzat, bakar batentzat agian, Paris beste tranpolin bat izan zitekeen.

Maria Jesus Villanuevaren kasua dugu hau. Arraizen 1934ko Abenduaren 19an jaioa, Alkaiagako Garakoetxea baserrian hazi zen. Beran, Hijas de la Caridad monja eskolan ikasketak amaitutzat eman ondoren, 1951n, 17 urte zituelarik Irungo Beraun Dorretxean neskame lanak betetzen hasi zen.

1954. urte inguruan, Robert Laffont paristarraren Hendaiako etxean hasi zen lanean. Familia honekin, Pariserat joan zen. Bertan frantsesa ikasi zuen eta baita ikasketak egin ere garai hartan ospetsua zen "Esmod" arropa- diseinu etxean.

24 urte zituela, goi mailako jostuna izateko titulua lortu zuen.

1958ean Paristik Londresera joan zen. Beranduago, Parisa itzulirik zenbait jantzi denda eleganteetan lan egin zuen: Ralux, Hermes...

Ondoren, Estatu Batuetara joateko asmoa bete zuen. Bertan, Fermín eta Martín bere bi anaiak bizi ziren. Maria Jesús Beverly Hillsen, aktoresa famatuen jantziak diseinatzen eta egiten aritu zen.

Bizi interesgarria benetan.

Esposatu ziren askok gaur egun ere pena dute Pariseko esperientzia bizitu ez izana.

Neska hauek ez ziren orokorki, baserrira esposatu. Areago, sasoia egindako neska gehienak, beraien herriak utzi eta inguruko hiri edo herri handiagoetara joan ziren bizitzera. Herriko bizimodua atzera utzi nahi izan zuten nonbait.

Teresa del Vallek (1985) Douglass aipatzen du zera esaterakoan:

Douglass constata un cambio en la actitud de la mujer respecto al caserío y a la vida tradicional; hay una negativa a casarse con un casero, sobre todo en mujeres que han salido a trabajar fuera del pueblo: “... en Echalar son las 


\title{
Rosa Arburua
}

chicas las que más critican la vida en la aldea, y las que más ganas tienen de abandonarla."

Nire ustez, sasoia egin zuten neskak ez ziren "casero" batekin esposatzekoaren aurkakoak. Azken finean, ezagutzen zituzten mutilak baserritarrak ziren. Baina, bai, baserriko etxekoandrea izatekoaren aurka agertzen ziren. Ez zuten herrian gelditu nahi izaten, ez zituzten maite baserriko giroa eta lanak eta hortik alde egin nahi zuten. Garai hartako sasoia egiten zuten nesken gizongai asko kontrabandistak izaten ziren eta irabazitako diru harekin baserritik kanpo bizitzeko ilusioa eta aukera izan zuten.

Douglass (1977) berak dioenez:

\begin{abstract}
La joven, al regresar, vuelve impresionada por lo que ha conocido y decepcionada por el "retraso" de la aldea. El jovén que regresa, vuelve a la aldea con unos ahorros que impresionan a sus amigos cuya aprobación es buena prueba de su éxito, mientras que las experiencias extranjeras de las jóvenes hacen que éstas queden alienadas de la vida de la aldea.
\end{abstract}

Sasoia egin zuten neskek gazte garaian ezagutu zuten bizimodutik kanpo egon nahi zuten. "Munduan zer zen ikusi genuen eta gure herritik kanpo beste gauza batzuk bazirela ohartu ginen."

Esposatu ondoren, ez dira etxeko andreak bakarrik izan. Askok, gehienek, nik dakidala, etxetik kanpoko lanak ere egin dituzte. Eta horietatik askok negozioren bat ere jarri zuten: Ultramarinos denda batek, besteak zapata-denda, bi ahizpek opari denda, beste batek elektrodomestikos deritzana, azken urte hauetan nekazalgo turismoa ere bai... Beti langile, beti berrikuntzaren atzetik!

\section{Erreferentziak}

Arburua, Rosa. 2005. 1940-60. Bortzirietako gaztiak. Irun: Alberdania.

Caro, Julio. 1986. Nosotros los vascos III. La crisis del caserío. Donostia: Lur.

Chueca, Josu eta Luís Fernández. 1997. "Espainiako Gerra Zibila Euskal Herrian", Andoain: Euskaldunon Egunkaria.

De Vega, Eulalia. 1992. La mujer en la historia. Salamanca: Anaya.

Del Valle, Teresa. 1985. Mujer vasca. Imagen y realidad. Bartzelona: Anthropos.

Douglass, William. 1977. Oportunidad y éxodo rural en dos aldeas vascas: Echalar y Murélaga. Donostia: Auñamendi. 


\section{Rosa Arburua}

Fernández, Silvia eta Paco Roda. 1998. Ellas, las mujeres en la historia de Pamplona. Iruñea: Iruñeko Udala.

Inchauspé, Véronique. 2001. Memoire d’hirondelles. Maule: Uhaitza Ikhertzaileak.

Merino, Fernando. 1984. El desarrollo económico de la cuenca del Bidasoa. Bidasoako ikaskuntzen aldizkaria 1. 105-144.

Paul, Juan Ignacio. 1980. Historia del País Vasco. Donostia: Haranburu.

Paul, Juan Ignacio eta bertze. 1995. Zubieta 1931-1936. Errepublika eta 1936ko gerra Baztan-Bidasoan. Irun: Luma.

Ugalde, Martín. 1982. Nueva síntesis de la Historía del País Vasco. Oiartzun: Sendoa. 